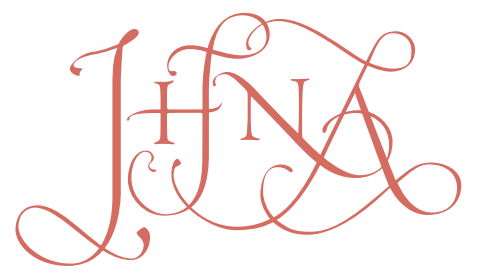

JOURNAL OF HISTORIANS OF NETHERLANDISH ART

\title{
COMMUNICATION, COLLABORATION, AND COLLEGIALITY: A TRIBUTE TO CAROL J. PURTLE
}

\author{
Anne W. Lowenthal
}

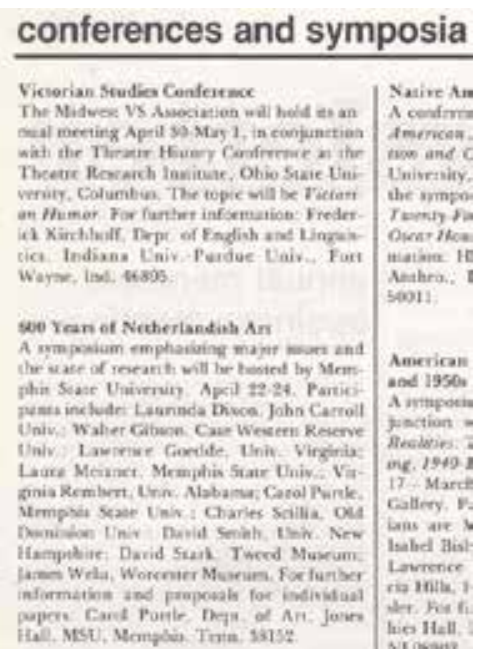

Fig. 1 The Call for Papers, CAA newsletter, Winter 1981/82

$\mathrm{I}$ $\mathrm{t}$ all began with "600 Years of Netherlandish Art," a symposium announced in the CAA Newsletter for Winter 1981/82 (fig. 1). Nearly three decades later, we hear that announcement as a clarion call, for this gathering was the progenitor of Historians of Netherlandish Art, heralding a new era in the field of Northern European studies. From those beginnings, HNA has grown to an international organization with over six hundred members, many of them young scholars for whom HNA's early years are as shrouded in the mists of history as the 1430s. The publication of this inaugural issue of the Journal of Historians of Netherlandish Art marks a milestone, an opportunity to pause and reflect on the genesis of HNA and on the enterprise and inspired leadership of the extraordinary woman who was its prime mover, Carol J. Purtle (1939-2008).

With the publication of her book The Marian Paintings of Jan van Eyck (Princeton University Press, 1982), Professor Purtle was evidently ready for a new challenge. Broadening her range, she conceived a gathering of scholars who would explore Netherlandish art from the fifteenth into the twentieth centuries.

This would be the first symposium to be held on the Memphis State University campus, and since there was no precedent Carol and her able assistant, Belinda Brooks Patterson, "pretty much wrote the rules," as Belinda remembers. They appealed to faculty members and friends of 
the university to provide hospitality for speakers and arranged an array of social gatherings to supplement purely scholarly activities. Registration for the symposium was to be free and open to the public. Belinda recalls that "the interaction and the networking made everyone feel so positive about what had happened that it carried over into the creation of HNA." Carol's effectiveness in marshaling resources for the achievement of a common goal was already in evidence.
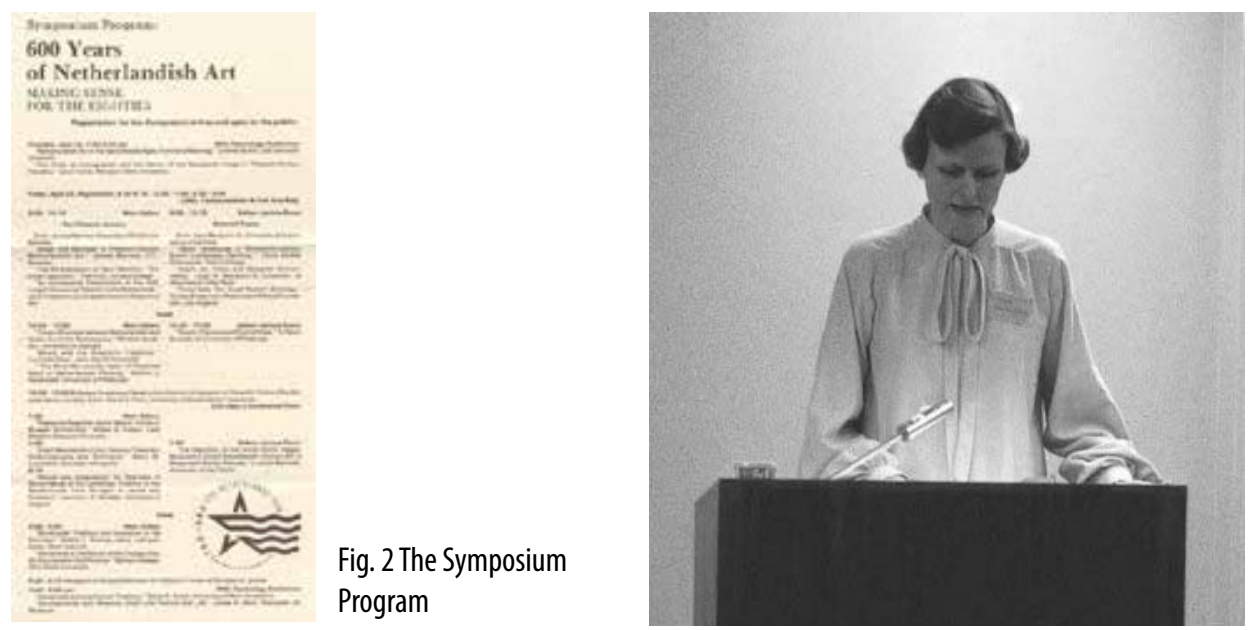

Fig. 3 Carol Purtle opens the Symposium

The symposium, “600 Years of Netherlandish Art: Making Sense for the Eighties," was planned for April 22-24, 1982, beginning Thursday evening and continuing through Saturday (fig. 2). Thirty-three speakers offered two keynote addresses, delivered talks in fourteen sessions, and shared ideas in two discussion panels. Paper topics ranged chronologically from "Netherlandish Art in the Early Middle Ages: Form and Meaning" to "Contemporary Dutch Art" and from the scholarly to the practical, with Jeremy Bangs, Archivist of the City of Leiden, offering a paper (read in his absence) entitled "General Problems in Archival Research: The Most Effective Ways to Use Dutch Archives." The ambience differed significantly from that at CAA sessions, which typically involved fewer speakers and a more limited range of topics. The theme, Netherlandish art over a period of six hundred years, provided both a unifying rubric and a challenging invitation to look beyond the boundaries of narrow specialization.

The bonds now familiar from HNA meetings and conferences were apparent as soon as participants met in Memphis for the opening of the symposium, over which Carol presided (fig. 3). We had all known one another by name, publications, and reputation but putting faces to these disembodied connections added an invaluable dimension. Opportunities for communication were exponentially enhanced. Questions could be posed and answered immediately, puzzling issues could be considered at leisure. Our shared interests generated shop talk on a deeply gratifying level.

In bringing this group together, Carol had skillfully identified an area of scholarship that was geographically and chronologically delimited but which encompassed wide stylistic variety and the achievement of major artists in the media of painting, graphics, tapestry, sculpture, and architecture. Moreover, by the early 1980s, the field of Netherlandish studies had attracted a critical mass of scholarly activity that was a key to the intensity and vigor of our exchange. The fact that the elders in our field were not present seemed to validate us as a new generation of scholars. 
Carol had also rightly anticipated the need to balance intense intellectualizing with serious socializing. Southern hospitality was on display at a cocktail reception at the Brooks Memorial Art Gallery (figs. 4-7) and a breakfast at the Dixon Gallery and Gardens (figs. 8-14), as well as at a dinner buffet hosted by Mr. and Mrs. E. M. Radcliffe on Friday evening. The special exhibition of Rembrandt etchings at the Brooks, planned to coincide with the symposium, was a major attraction. David Bowman led a bus tour of Memphis on Saturday afternoon, covering the city's historic, architectural, and cultural highlights. That evening, the art department faculty hosted an informal cocktail buffet at the home of Larry and Mattie Edwards. Needless to say, all of these gatherings were opportunities for the ìcommunication and collaborationî promised in the symposium's announcement.

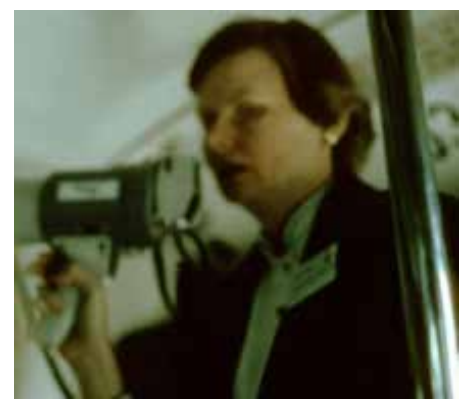

Fig. 4 Carol on the bus to the Brooks Memorial Art Gallery

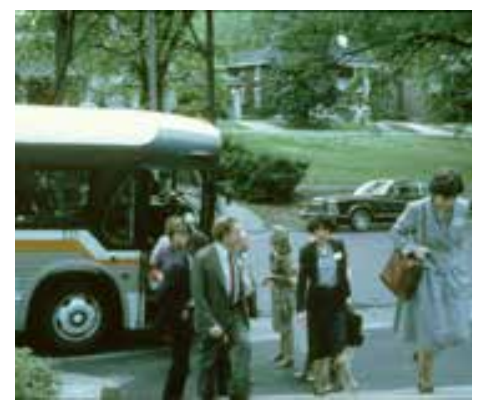

Fig. 5 In the foreground: Walter Strauss, Barbara Haeger, and Mona Spearing Barzizza, a friend of the Art Department
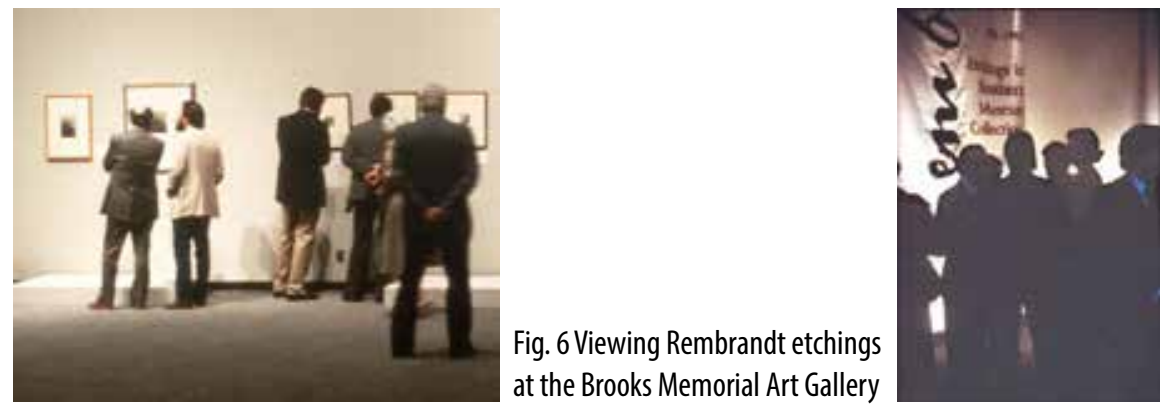

Fig. 7 Viewing Rembrandt etchings at the Brooks Memorial Art Gallery, with Carol silhouetted at the right

At the end of the symposium, we met at a local restaurant for dinner, and already there was talk of continuing the collegial contacts and friendships we had forged during our three days together. Not long afterwards, Carol approached several of us to explore the possibility of establishing an organization that would build on our common interests. The essential question was whether the energy that infused the symposium had been spent, or whether that spirit could spark broader, sustained interest among scholars of Northern art.

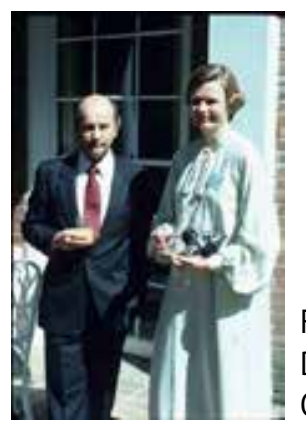

Fig. 8 Carol with Michael Milkovitch, Director of the Dixon Gallery and Gardens

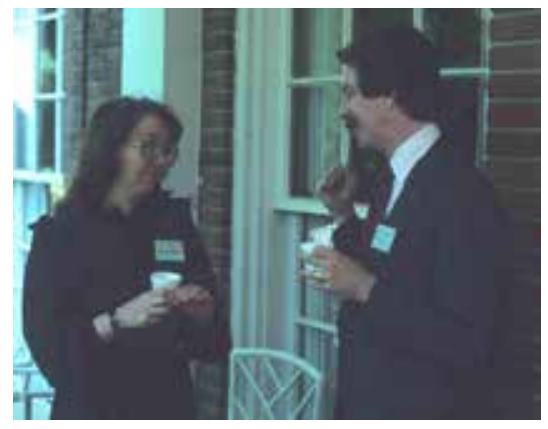

Fig. 9 Laurinda Dixon and Morris Perinchief 
Encouraged by the enthusiastic responses to her inquiries, Carol circulated a flyer at the Annual CAA Meeting the following year, 1983, in Philadelphia, announcing a noontime meeting of scholars of Northern European art. That meeting (the founding of Historians of Netherlandish Art) was a heady moment and represented not only a reunion of participants in the Memphis symposium but also the welcoming of other scholars attracted by the prospect of a group focused on Northern European studies. With Carol presiding over the expectant crowd, an organizational structure emerged. Carol was unanimously elected president, with Laurinda Dixon as vice president. The secretary-treasurer, Kahren Hellerstedt, collected dues of \$10. Walter Strauss, Gloria Fiero, and Jane Friedman agreed to provide the HNA Newsletter; Volume 1, no. 1 appeared the following July. Eighty members would complete information forms in time to be included in the first membership directory, for 1983.

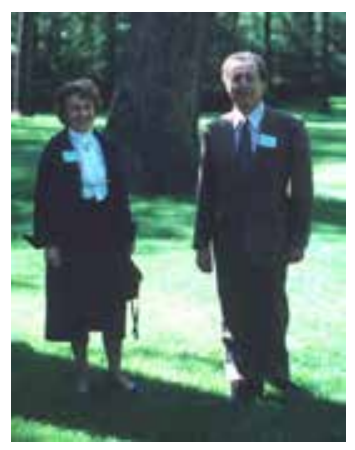

Fig. 10 Mary Margaret Ross, a member of the Memphis State Art Department faculty, and Walter Strauss

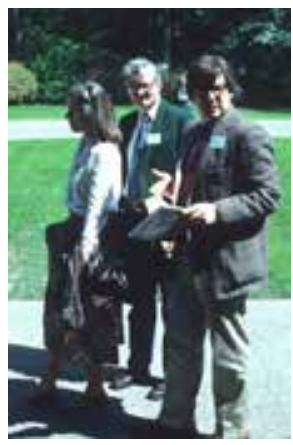

Fig. 11 Diane Scillia, Walter Gibson, and Charles Scillia

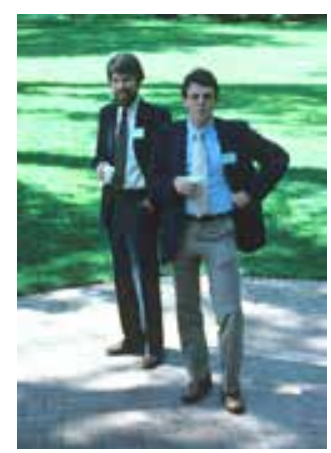

Fig. 12 Larry Goedde and David Smith

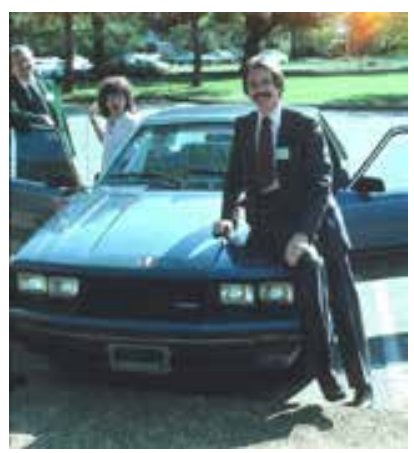

Fig. 13 Walter Gibson, Gloria Fiero, and Morris Perinchief

Carol's guidance of HNA through its crucial early years shaped a vigorous organization. Summarizing progress in the Newsletter for January 1985, she reported that CAA had approved HNA's application for status as an Affiliated Society. HNA's first officers, elected in Philadelphia, had continued to serve but were now engaged not only in day-to-day operations but also in tasks relating to a major international research conference, planned for October 1985. A tentative program was included in the January 1985 Newsletter, together with a summary: "This research conference will convene for the first time the majority of major American scholars in the field of Northern European Art History (i.e., those specializing in the art of Belgium, Germany and the Netherlands, 1400-1700). It is designed to assess past contributions and direct some aspects of future research efforts in this scholarly discipline. The presence of seven major European scholars on the program will also help focus the field toward international collaboration. Over 200 scholars and graduate students are expected to attend the conference, which will be held at the University of Pittsburgh, October 10-12, 1985."

The Pittsburgh conference, a resounding success, boosted HNA's membership to 183. New officers were elected in February 1986 at the annual meeting, held in New York, with Laurinda Dixon succeeding Carol as president. Carol, however, would remain actively involved, never hovering, but continuing to nurture the burgeoning organization. By February 1987, five years after the by then legendary Memphis symposium, membership stood at 259, with the U.S., Canada, the Netherlands, and Belgium represented along with England, Germany, Hungary, Israel, Japan, and 
Switzerland.

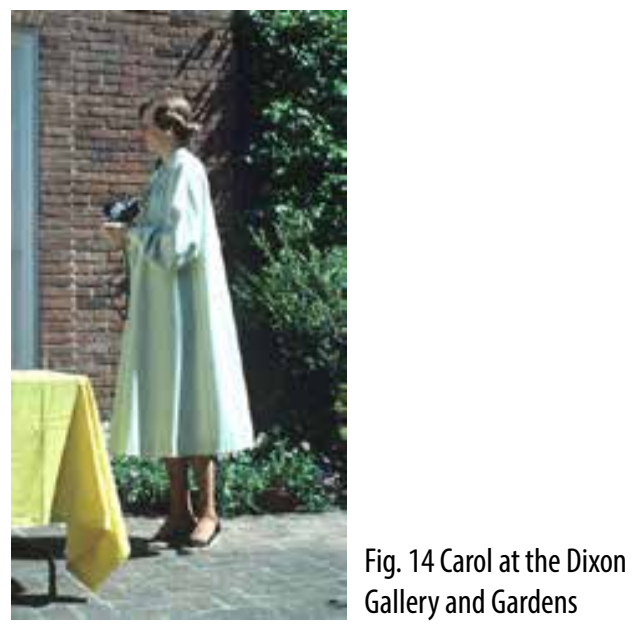

Historians of Netherlandish Art became a model for several other Affiliated Societies within CAA. In recognizing the need for an organization that would bring together scholars in Northern European art, Carol Purtle was a visionary whose grasp equaled her reach. A natural leader, she was supremely well-organized and detail-oriented, articulate and persuasive. She inspired us with her sense of the possible, always presented with a quiet but forceful enthusiasm, along with abiding good humor. These skills and talents were very much of this world, but they were clothed in a calm grace and elegance that reflected her commitment to the Community of the Religious of the Sacred Heart. Her work as founder of HNA was of a piece with her studies of Jan van Eyck and with Van Eyck's art itself, marked by dedication to both expansive vision and firm realization.

Special thanks to James Marrow and Belinda Brooks Patterson for providing photographs; those for figure numbers 4-7 were taken by Sue S. Miller, figure numbers 3, 8-14 by James Marrow. I also thank Belinda for clarifying and enhancing the historical record by sharing her memories of working with Carol over many years. Thanks also to Kristin Belkin for providing archival materials and to Molly Faries for help with illustrations.

Anne W. Lowenthal, an independent scholar based in New York City, has continued her studies in Dutch mannerism since presenting a paper, Dutch Mannerism in Our Century: Towards a Historiography and Definition, at the Memphis Symposium. She was a founding member of Historians of Netherlandish Art and its third president.

\section{List of Illustrations}

Fig. 1 The Call for Papers, CAA newsletter, Winter 1981/82

Fig. 2 The Symposium Program

Fig. 3 Carol Purtle opens the Symposium

Fig. 4 Carol on the bus to the Brooks Memorial Art Gallery 
Fig. 5 In the foreground: Walter Strauss, Barbara Haeger, and Mona Spearing Barzizza, a friend of the Art Department

Fig 6. Viewing Rembrandt etchings at the Brooks Memorial Art Gallery

Fig. 7 Viewing Rembrandt etchings at the Brooks Memorial Art Gallery, with Carol silhouetted at the right

Fig. 8 Carol with Michael Milkovitch, Director of the Dixon Gallery and Gardens

Fig. 9 Laurinda Dixon and Morris Perinchief

Fig. 10 Mary Margaret Ross, a member of the Memphis State Art Department faculty, and Walter Strauss

Fig. 11 Diane Scillia, Walter Gibson, and Charles Scilli

Fig. 12 Larry Goedde and David Smith

Fig. 13 Walter Gibson, Gloria Fiero, and Morris Perinchief

Fig. 14 Carol at the Dixon Gallery and Gardens

Photo credits: Figs. 4-7 by Sue S. Miller; Figs. 3, 9-14 by James Marrow. 